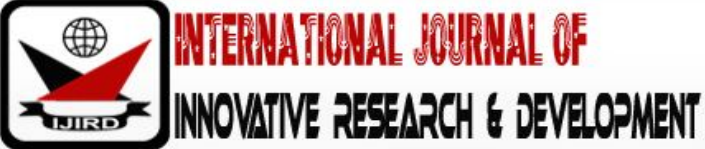

ISSN 2278 - 0211 (Online)

\section{How do You Measure Trust?: Trust Taxonomies \& Measurement Tools Revisited}

\author{
Dr. Sheikh Shamim Hasnain \\ Senior Lecturer, Department of Business Administration, The British University in Egypt, Egypt
}

\begin{abstract}
:
This article, based on literature, is an assembly of various trust taxonomies and measurement tools. Trust is one of the important subjects of many social scientists. Many researchers have examined its impacts on various contexts. In organizations trust helps achieving the desired objectives with reduced costs. Researchers have classified trust in various ways. Trust is a disclosure of weaknesses by a party to another believing that the later would not do any harm to the former. Literature finds numerous classifications of trust, namely, deterrent based trust, knowledge based trust and identification based trust. Some researchers find trust as calculus based, knowledge based and identification based. Cognitive, emotional and benevolence is a classification of trust identified by the social scientists. Trust is also divided into character-based, process-based, and institutional based. A widely used classification of trust is: Ability based trust, benevolence based trust and integrity based trust. Researchers have used various dimensions and scales of trust and investigated their impacts on various issues of the organizations.
\end{abstract}

Keywords: Trust, taxonomies, measurement tools

\section{Introduction}

Trust is an important variable for many social science disciplines (Bhattacherjee, 2002). In organisations, it helps achieve smooth knowledge transfer (Ko, 2010; Hasnain, 2017; Holstle \& Fields, 2010; Holstle, 2003), effective leadership (Bennis and Nanus, 1985) and productivity. Further, trust ensures less control/monitoring and reduces expenditures. So, it is crucial to know: (i) classifications of trust and their impact and (ii) measurement tools of trust. Mayer, Davis and Schoorman (1995) finds trust as "the willingness of a party to be vulnerable to the actions of another party based on expectation that the other will perform a particular action important to the truster, irrespective of the ability to monitor or control that party" (p. 712). Actually " trust is one party's willingness to be vulnerable to another party based on the belief that the later party is (a) competent, (b) open, (c) concerned, and (d) reliable" (Mishra (1996, p.265).

\section{Trust Taxonomies}

Many researchers (Shapiro, Sheppard and Cheraskin, 1992; Lewicki and Bunker, 1996; Lewis and Weigert, 1985; Kramer, 1999; to note a few) have identified different classifications of trust. Some of the classifications are appended below:

\subsection{Shapiro, Sheppard and Cheraskin (1992)}

Shapiro, Sheppard and Cheraskin (1992) find three types of trust, based in deterrence, knowledge and identification, in the business relationship. Deterrence based trust is related to fear of punishment. Here disobedience to any instruction is a punishable offence. Knowledge based trust is based on the prediction on the behaviour of another party. Gradual acquaintance and familiarity with others helps to have knowledge of each other's behaviours, abilities, reliability and honesty. Identification based trust is based on shared values, and empathy and considerations for each other. In brief, one party may put itself in another's shoes.

\subsection{Lewicki and Bunker (1996)}

Extending the idea of Shapiroet al. (1992), Lewicki and Bunker (1996) term deterrence based trust as 'calculusbase trust', arguing, "deterrence based trust is grounded not only in the fear of punishment for violating the trust but also in the rewards to be derived from preserving it" (p. 120). Lewicki and Bunker (1996) also find that these three types of trust, are sequential, and trust on one level facilitates the progress of trust to the next.

\subsection{Lewis and Weigert (1985)}

Lewis and Weigert (1985) differentiate three types of trust, based on cognitive, emotional and behavioural elements. Cognitive is the primary base of establishing trust between the trustee and the trustor. They argued, "we cognitively choose whom we will trust in which respects and which circumstances, and we base the choice on what we 
take to be 'good reasons', constituting evidence of trustworthiness" (p.970). Emotional trust is complementary to cognitive trust. Betrayal of trust brings serious pain and emotional outrage in the betrayed, and may also in the betrayer. Behavioural trust is based on the expected actions of the parties involved in the effort. These three types of trust are interrelated. Any kind of trust has at least some cognitive element.

\subsection{Kramer (1999)}

Kramer (1999) describes six bases and classes of trust. (i) dispositional trust is common belief about other people (ii) previous trust related experiences and behaviour is the basis of the present trust engagement behaviour is termed as history based trust (iii) third parties may be important sources of information to trust somebody (iv) category-based trust refers to trust predicted on information regarding a trustee's membership in a social or organisational categoryinformation which, when silent, often unknowingly influences others' judgement about their trustworthiness (v) trust on the role of an individual in the organisation is addressed as role-based trust, (vi) rule- based trust is predicted not on a conscious calculation of consequences, but on shared understandings regarding the system of rules appropriate behaviour.

\subsection{McKnight, Cummings and Chervany (1998)}

McKnight, Cummings and Chervany (1998) propose an interdisciplinary model of trust concepts, identifying disposition to trust, institution based trust, trusting beliefs and trusting intention as the constructs for its initial formation. Disposition to trust is associated with the personality of the individual, a person's general willingness to believe others or situations. Institution based trust is based on the situational normality and structural assurances. Situational normality is a belief which articulates that the situation is conducive, so success is likely to happen. Structural assurances mean the trust of the trustors on capabilities of the institutional structure, rules, regulations, guarantees, legal recourse, to safeguard their interests. Trusting belief is based on the commonly used traits of benevolence, competence, honesty and predictability. Trusting belief and trusting intention are closely linked. McKnight et al. (1998) argue, "logically, if one believes that the other party is benevolent, competent, honest and predictable, one is likely to form a trusting intention toward that person. Therefore, trusting belief will positively impact trusting intention" (p. 479-480).

\subsection{Zucker (1986)}

Zucker (1986) identifies three types of trust on the basis of source. Characteristic based trust is rooted in the person and their character, qualities, background. Process based trust develops on the past and expected interactions. Institutional trust is attached to the formal social structure.

\subsection{Castaldo (2003)}

Castaldo (2003) classifies trust typologies into target-based, content based and strength based. The target of trust distinguishes the application of trust at the relational level, whether institutional, systems, inter-organisational, or interpersonal. The content of trust is antecedent based, calculative, rational, and cognitive. Strength based trust is based on the quality and consistency of trust, from fragile to strong or full trust. Castaldo (2003) also exhibites comprehensive typologies of trust based on the works of researchers, and put those into seven criteria; (i) based on trust dimensions: Ideological, cognitive, emotional and routine trust ( Lewis and Wiegert, 1985); affective, cognitive and behavioural trust (Cummings and Bromiley, 1996); behavioural and intentional trust (Nooteboom, Berger and Noorderhaven, 1997); affectbased and cognition based trust (McAllister, 1995); reliability and emotional trust (Johnson-George and Swap, 1982); values, attitudes and mood and emotion (Jones and George, 1988); institutionalisation and habitualisation (Nooteboom, Berger and Noorderheaven, 1997); competence and goodwill based dimensions (Nooteboom, 1996) (ii) relational layer: calculative, institutional and personal trust (Williamson, 1993); institutional-based, system-based and societal trust (Lane, 1998); individual, interpersonal, institutional trust (Lewicki and Bunker, 1995); calculative, relational and institutional trust (Rousseau, Sitkin, Burt and Camerer, 1998) (iii) Contents and antecedents: calculative, knowledge-based and institutional (Lewicki and Bunker, 1996); deterrence-based, knowledge-based and identification based trust (Shapiro, Sheppard and Cheraskin (1992; Sheppard and Tuckinsky, 1996); calculative, cognitive and normative trust (Lane, 1998); contractual trust, competence trust and goodwill trust (Sako, 1992; Sako and Helper, 1998); predictability-based and value based trust (Sitkin and Roth, 1993); predictability and explorative trust (Huemer, 2000) (iv) Strength/ quality: full, instable and hopeful trust (Andaleeb, 1992); thick or thin, weak or strong, fragile or resilient trust (Meyerson, Weick and Kramer, 1996); weak, semi-strong and strong trust (Burney and Hansen, 1994) (v) development processes: characteristicbased, process-based, institution based (Zucker, 1986); calculative processes, predictive processes, intention based processes, knowledge based processes, transfer based processes (Doney and Cannon, 1997; Doney, Cannon and Mullen, 1998); (vi) Contiguous concepts: Spontaneous trust, generated trust, manipulation and capitulation (Hardy, Philips and Lawrence, 1998); trust, faith, confidence and reputation (Luhmann, 1989); trust, power and commitment (Gambetta, 1989; Morgen and Hunt, 1994); rational prediction, probable anticipation, uncertainty, panic, fate and faith (Lewis and Wiegert, 1985) (vii) Miscellaneous classifications: basic trust, guarded trust and extended trust (Brenkert, 1998); deterrence, obligation, discovery internalization (Sheppard and Sherman, 1998); task-focused, fiduciary and relational forms of trust (Barber, 1983). 
Mayer et al. (1995) developed a model (Figure-1) on the antecedents and outcomes of trust. proposing ability, benevolence and integrity as the factors of perceived trustworthiness.

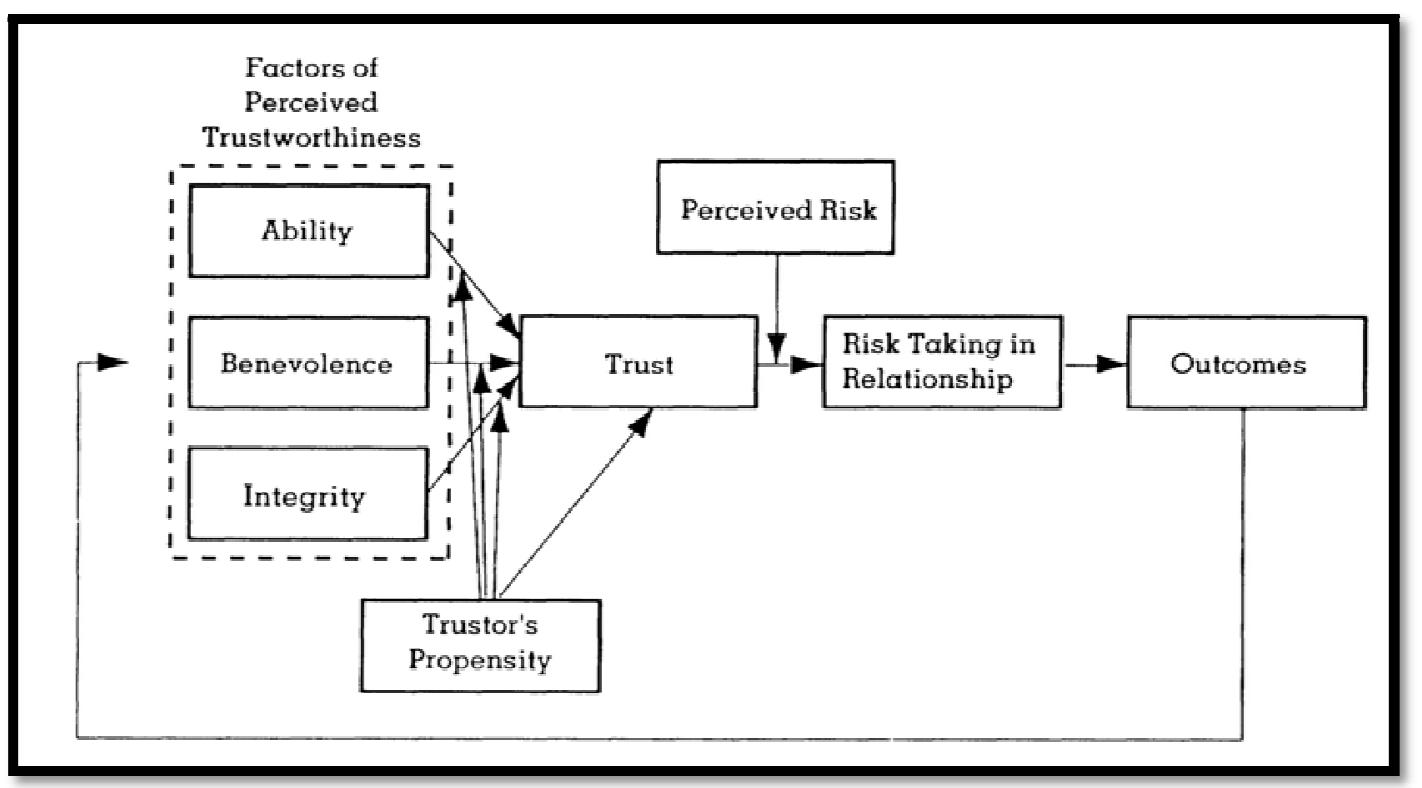

Figure 1: Trust (Mayer et al., 1995, p. 715

Mayer et al. (1995) find, "each contributes a unique perceptual perspective from which to consider the trustee, while the set provides a solid and parsimonious foundation for empirical study of trust for another party" (p. 717). These are the determinants for the trustor to trust the trustee: (i) ability (ii) benevolence and (iii) integrity. Ability: Mayeret al. (1995) argue, "the domain of the ability is specific because the trustee may be highly competent in some technical area, affording that person trust on tasks related to that area. However, the trustee may have little aptitude, training, experience in another area ..." (p. 717).Benevolence: "the extent to which a trustee is believed to want to do good to the trustor, aside from an egocentric profit motive" (p. 718). Integrity: "the trustor's perception that the trustee adheres to a set of principles that the trustor finds acceptable" (p. 719). These three trust-antecedents may be excellent independent variables to examine their impact on various dependent variables of the organisations. For example, Ko (2010) could examine their impact on knowledge transfer in the organisations.

The trust taxonomies at a glance is shown as fol: (i) Deterrence-based trust, Knowledge-based trust and Identification based trust (Shapiro et al., 1992) (ii) Cognitive, Emotional and Benevolence trust (Lewis and Weigert, 1985) (iii) Dispositional, History, third parties, Category, role and rule based trust (Kramer, 1999) (iv) Disposition to trust, institution based trust, trusting belief and trusting intention (McKnight, et al. 1998) (v) Calculus -based, Knowledgebased , identification based trust (Lewicki and Bunker, 1996) (vi) Characteristic- based trust, Process-based trust and Institutional based trust ( Zucker, 1986) (vii) Target based, Content based and Strength based trust (Castaldo, 2003) (viii) 7-Classifications based on the works of researchers (Castaldo, 2003) : Based on trust dimension, Relational layer, Contents and antecedents, Strength/ quality, Development processes, Continuous concepts, Miscellaneous classifications

\section{Measurement of Trust}

There is no specific tool for the measurement of trust. Several researchers (Ko, 2010; Lucas, 2005; McAllister, 1995; Cummings and Bromiley, 1996; Cook and Wall, 1980; Coote, Forrest and Tam, 2003; Smith and Barclay, 1997) have made efforts to measure trust. Many quantitative researchers have dimensioned trust and those are employed as independent variables to examine their impacts on the chosen dependent variables in various contexts. Here number of items differs on the context of the research. Some researchers have used five point Likert scale and some of them used eight points. However, hardly any qualitative measurement tool is notice in literature.

Seppänen, Blomqvist and Sundqvist (2007) find the differences and inconsistencies onthe measurement issues of trust. For example, Ganesan (1994) dimensioned trust into credibility and benevolence. The vendor's credibility was measured on seven, and benevolence on five items. The retailer's credibility was measured on four, and benevolence on three items. Others factors were tested in a total of 24 items. Aulakh, Kotabe and Sahay (1996) put confidence, reliability and integrity under trust. They used four items for measuring continuity expectations, three for flexibility, two for information exchange, four for output control, and three for trust. All items were measured on a scale of one to five (strongly disagree-strongly agree). Chow and Holden (1997) measured reliability and truth/ honesty using three items measuring trust in the sales person ('anyone who trusts them is asking for trouble'). Three items measured trust in the company. For instance, 'this company is basically honest". The five point Likert scale was used to assess. Doney and Cannon (1997) studied the credibility and benevolence dimensions of trust. Trust of the supplier firm, trust of salespersons and antecedents were investigated with eight, seven and 41 items respectively. Smith and Barclay (1997) had the dimensions of honesty/ integrity, reliability/ dependability, responsibility, likeability and judgment. 23 items were used to measure trustworthiness, and 27 items to measure trusting behaviours. Each factor of organizational difference was measured, and a total of fifteen items were used. Norman (2002) examined the competence-based trust and good will 
trust, itemising for trust; (i) "we can trust our partner to abide by the alliance agreement" (ii) there is high level of trust in the working relationship with our partner (iii) we believe that our partner's decision will be beneficial to the alliance (iv) we trust that our partner's decisions will be beneficial to our firm.

In addition to these, many other researchers have developed various trust measurement instruments. An exhibitof important trust measurement instruments is show as: (i) Scale of Specific Interpersonal Trust (Johnson-George and Swap, 1982) (ii) 8-Scale Dyadic Trust Scale( Larzelere and Huston, 1980) (iii) 136 items: Organisational Trust Inventory (OTI) (Cummings and Bromiley, 1996) (iv)Trust in Management(Cook and Wall, 1980) (v) Trust scale: 26-items based on reliability and dependability(Rempel, Holmes and Zanna, 1985) (vi) Scale to measure interpersonal trust (Rotter, 1967) (vii) 13-core constructs put into three dimensions( emotive, cognitive, behavioural) (Ashleigh andStanton, 2001) (viii) Psychometric properties (Propensity to trust Survey i. e. PTS) and The Investment game

(Evans and Revelle, 2008).

\section{Conclusion and Future Research}

Trust is highly social and context specific in nature. Various researchers have given the different classifications of trust and empirically examined their impacts on different contexts. Quantitative researchers have used many trust measurement tools for their studies. These researchers have used measuring tools from the specific context, as there is no particular trust measurement tool for a particular situation. It may differ from individual to individual, organisation to organisation and situation to situation and it also even depends on the choice of a particular researcher of what measurement instrument is to be used. Ashleigh, Connell \& Klein(2003) find, "incongruence still exists between definition and measurement across literature. This problem exists because research methods have emanated from different sources and theoretical perspectives and so often the type of measurement may not contextually relevant to the area of research" (p. 5). To substantiate the statement they also cited different examples, notably, Munir and Moray (1996), who used the elements from psychological interpersonal trust theories to measure trust in technology. They repeatedly blamed this type of research by arguing, "such research has been accused of being too parsimonious with its definition of trust, whilst ignoring the social context or situation under investigation" (p. 5).It is unfortunate to note, the qualitative researchers have ignored to find out the trust measurement tools.

Whatever the case may be, trust is an important multi-disciplinary variable which is used in different contexts by the researchers. Future researchers may empirically examine the different classifications and measurement tools inthe new contexts. Further, qualitative research on trust measurement may open a new horizon in the academic and corporate worlds!

\section{References}

i. Andaleeb, S. S. (1992). The trust concept: Research issues for channel of distribution. InJ.N. Sheth (ed.) Research in Marketing, vol. 11 (pp. 1-34). JAI Press Inc.

ii. Ashleigh, M., Connell, C. \& Klein, J. H. (2003, October). Trust and knowledge transfer: Anexplanatory framework for identifying relationships within communities of practice. The EIASM Second Workshop on Trust Within and Between Organizations, Amsterdam.

iii. Ashleigh, M. J. \& Stanton, N. A. (2001). Trust: Key elements in human supervisory control domains. Cognition Technology \&Work, 3, 92-100.

iv. Aulakh, P.S., Kotabe, M. \&Sahay, A. (1996). Trust and performance in cross-border marketingpartnerships: A behavioural approach. International Business Studies, 27 (5), 1005-1032.

v. Barber, B. (1983). The Logic and Limits of Trust. NJ: Rutgers University Press.

vi. Bennis, W. G. \& Nanus, B. (1985). Leaders: The Strategies for Taking Charge. NY: Harper \& Row.

vii. Bhattacherjee, A. (2002). Individual trust in online firms: Scale development and initial test. Journal of Management Information Systems, 19 (1), 211-241.

viii. $\quad$ Brenkert G.G., (1998), Trust, Morality and International Business, in C. Lane \& R.

ix. Bachmann (eds.) Trust Within and Between Organizations. Conceptual Issues and Empirical Analysis. Oxford University Press, Oxford, pp.273-297.

x. Burney, J. B. \& Hansen, M. H. (1994). Trustworthiness as a source of competitive advantage. Strategic Management Journal, 15, 175-190.

xi. Castaldo, S. (2003). Trust variety-conceptual nature, dimensions and typologies. IMP 2003

xii. Conference, Lugano, Switzerland (4-6 Sept). [Available at: http:/ / www.impgroup.org/ uploads/ papers/ 4317.pdf, Accessed: 11 th Sept, 2018].

xiii. Chow, S. \& Holden, H. (1997). Toward understanding a loyalty: The moderating role of trust.Journal of Managerial Issues, 9 (3) , 275-298.

xiv. Cook, J. \& Wall, T. (1980). New work attitude measures of trust, organizational commitment and personal need non-fulfilment. Journal of Occupational Psychology, 53,

xv. 39-52.

xvi. Coote, L., Forrest, E. J. and Tam, T. W. (2003). An investigation into commitment in non-Western industrial marketing relationships. Industrial MarketingManagement,32(7), 595-604

xvii. Cummings, L. L. \& Bromiley, P. (1996). The organizational trust inventory (OTI):

xviii. Development and validation. In R.M. Kramer \& T. R. Tyler (Eds.), Trust in Organizations: Frontiers of Theory and Research, (pp. 302-330). Thousand Oaks, CA: Sage Publications, Inc. 
xix. Doney, P. M.\& Cannon, J. P. (1997). An Examination of the nature of trust in Buyer-seller relationships. The Journal of Marketing, 61, 35-51.

xx. Doney, P. M. Cannon, J. P. \& Mullen, M. R. (1998). Understanding the influence of national culture on the development of trust. Academy of Management Review, 23 (3), 601-620.

xxi. Evans, A. M. \& Revelle, W. (2008). Survey and behavioural measurements of interpersonal trust. Journal of Research in Personality, 42, 1585-1593.

xxii. Gambetta D., (1989), Possiamo fidarci della fiducia? in D. Gambetta (ed), Trust. Making and Breaking Cooperative Relations, Basil Blackwell Ltd., Oxford (pp.275-309- Italian).

xxiii. Hardy, C. Philips, N. \&Lawrence, T. (1998). Distinguishing trust and power in interorganizational relations: Forms and facades of trust. In C. Lane \& R. Bachmann(eds.) Trust within and between Organizations, Conceptual Issues and Empirical Analysis, Oxford University Press, Oxford (pp. 64-87)

xxiv. Hieronymi, P. (2008). The reasons of trust. Australian Journal of Philosophy, 86 (2), 213-236.

xxv. Hasnain, S. S. (2017). Trust-A Catalyst to Knowledge Transfer: Contemporary Studies. Advances in Social Sciences Research Journal, 4 (1), 29-40.

xxvi. Holste, J. S. \& Fields, D. (2010). Trust and tacit knowledge sharing and use. Journal of Knowledge Management, $14(1), 128-140$.

xxvii. Huemer, L. (2000). Beyond predictability: Employing trust in Business Relationships, working paper, Norwegian School of Management, Sandvika.

xxviii. Johnson-George, C. \& Swap, W. C. (1982). Measurement of specific interpersonal trust: Construction and validation of a scale to assess trust in a specific other.

xxix. Journal of Personality and Social Psychology, 43 (6), 1306-1317.Ko, D. (2010). Consultant competence trust doesn't pay off, but benevolence trust does! Managing knowledge with care. Journal of Knowledge Management, $14(2)$.

xxx. Kramer, R. M. (1999). Trust and distrust in organisations: Emerging perspectives, enduring questions. Annual Review of Psychology, 50, 569-598.

xxxi. Lane, C. (1998). 'Theories and issues in the study of trust'. In C. Lane and R. Bachmann (eds.) Trust within and between Organisations: Conceptual and Empirical Application. Oxford: Oxford University Press.

xxxii. Larzelere, R. E. \& Huston, T. L. (1980). The Dyadic trust scales. Journal of Marriage and the Family, 42 (3), 595604.

xxxiii. Lewicki, R. J. \& Bunker, B. B. (1996). Developing and maintaining trust in work relationship. In R. M. Kramer \& T. R. Tyler(Eds.), Trust in Organizations: Frontiers of Theory and Research, (pp.114-139). CA: Sage Publications.

xxxiv. Lewis, D. J. \&Weigert, A. (1985). Trust as a social reality. Social Forces, 63(4), 967-985.

xxxv. Lucas, L. M. (2005). The impact of trust and reputation on the transfer of best practices. Journal of Knowledge Management, $9(4)$, 87-101

xxxvi. Luhmann, N. (1979). Trust and Power. Chichester: John Wiley \& Sons

xxxvii. Luhmann, N. (1988). Familiarity, confidence, trust: Problems and alternatives. In D. G.

xxxviii. Gambetta (Ed.), Trust: 94-107.

xxxix. Luhmann N., (1989). Familiarita', confidare e fiducia: problemi e alternative, in Gambetta D. (ed.),Trust. Making and Breaking Cooperative Relations, Basil Blackwell Ltd., Oxford.

xl. Mayer, R.C., Davis, J.H. \& Schoorman, F.D. (1995). An integrative model of organizational trust. Academy of Management Review, 20 (3), 709-734

xli. McAllister,D.J. (1995).Affect- and cognition-based trust as foundations for interpersonal cooperation in organizations. The Academy of Management Journal, 38(1),24-59.

xlii. McKnight, D. H., Cummings, L. L. \& Chervany, N. L. (1998). Initial trust formation in new organizational relationships. The Academy of Management Review, 23 (3),473- 490.

xliii. Meyerson, D. Weick, K. E. and Kramer, R.M. (1996). Swift trust and temporary groups. In R. M. Kramer \& T. R. Tyler ( Eds.), Trust in Organizations: Frontiers of Theoryand Research (pp.166-195), Thousand Oaks, CA: Sage Publications, Inc.

xliv. Mishra, A. K.(1996). 'Organizational response to crisis: The century of trust', in R. M. Kramer \& T. R. Tyler ( eds.), Trust in Organizations: Frontiers of Theory and Research, California: Sage Publications, pp. 261-287.Morgan R.M. $\&$ Hunt S.D., (1994). The Commitment-Trust Theory of Relationship

xlv. Marketing. Journal of Marketing, 58 (july), 20-38.

xlvi. Muir, M. \& Mory, N. (1996). Trust in automation, part-II: Experimental studies of trust and human intervention in a process control simulation. Ergonomics, 39, 429-460.

xlvii. Nooteboom, B. (1996). Trust-based forms of governance: A process and control model. Organization Studies, 17, 985-1010.

xlviii. Nooteboom, B., Berger, H. \& Noorderhaven, N. G. (1997). Effects of trust and governance on relational risk. The Academy of Management Journal, 40 (2), 308-338.

xlix. Norman, P. M. (2002).Protecting knowledge in strategic alliances. Resource and relational characteristics .Journal of High Technology Management Research, 13 (2), 177-202.Rempel, J. K., Holmes, J. G. \& Zanna, M. P. (1985). Trust in close relationships. Journal of

l. Personality and Social Psychology, 49 (1), 95-112. Rotter, J. B. (1967). A new scale for measurement of interpersonal trust. Journal of

li. Personality, 35 (4), 651-665. 
lii. Rousseau, D. M., Sitkin, S. B., Burt, R. S. and Camerer, C. (1998). Not so different after all: A cross discipline view of trust. The Academy of Management Review, 23 (3),393-404.

liii. Sako, M, (1992). Prices, Quality and Trust. Inter-firm Relations in Britain and Japan. Cambridge: Cambridge University Press

liv. Sako, M. \& Helper, S. (1998). Determinants of trust in supplier relations: Evidence from the automotive industry in Japan and the United States. Journal of Economic Behavior\& Organization,(34), 3, 387-417.

lv. Seppänen, R., Blomqvist, K. \& Sundqvist, S. (2007). Measuring inter-organizational trust- acritical review of the empirical research in 1990-2003. Industrial Marketing Management, 36, 249-265.

lvi. Shapiro, D. Sheppard, B. H. \& Cheraskin (1992). Business on a hand shake. The Negotiation Journal, 8, 365-378.

lvii. Sheppard, B. H. \& Sherman, D. M. (1998). The Grammars of trust: A model and general implications. The Academy of Management Review, 23 (3), 422-437.

lviii. Sheppard, B. H. \& Tuchinsky, M. (1996). Micro-OB and the network organization. In R. M.Kramer \& T. R. Tyler ( Eds.), Trust in Organizations: Frontiers of Theory and Research, (pp.140-165). Thousand Oaks, CA: Sage Publications, Inc.

lix. Sitkin, S.B.,\&Roth, N.L.(1993). Explaining the limited effectiveness of legalistic "remedies" for trust/ distrust. Organization Science, 4, 367-392.

lx. Smith, J.B. \&Barclay, W.B. (1997). The effects of organizational differences and trust on the effectiveness of selling partner relationships. Journal of Marketing, 61 (1), 3-21.

lxi. Soh, H. Reid, L.N. \& King, K. W. (2007). Trust in different advertising media. Journalism and Mass Communication Quarterly, 84 (4) (Autumn), 455-476.

lxii. Zucker, L.G., (1986). Production of trust: Institutional sources of Economic structure, 1840-

lxiii. 1920. Research in Organizational Behaviour, 8, 53-111.

lxiv. Zucker, L. G., Darby, M. R., Brewer, M. B., Peng, Y. ( 1996). Collaboration structure and information dilemmas in biotechnology: Organizational boundaries as trust production. In R. M. Kramer \& T. R. Tyler ( Eds.), Trust in Organizations: Frontiers of Theory and Research, (pp.90-113). Thousand Oaks, CA: Sage Publications, Inc. 